\title{
VÝVOJ ZÁVĚREČNÝCH ZKOUŠEK V UČEBNÍCH OBORECH, ANEB SITUAČNÍ ZPRÁVA A VÝHLED DO BUDOUCNA
}

\author{
1 ÚVOD A KONTEXT
}

Ačkoliv autoři Bílé knihy (Národní program rozvoje vzdělávání v České republice 2001) v rámci strategických změn explicitně neuvádějí v oblasti „monitorování a hodnocení kvality a efektivity vzdělávání" nové pojetí závěrečných zkoušek v oborech poskytujících střední odborné vzdělání s výučním listem (tzv. učebních oborech), tak přesto zde dochází v posledních letech, za menšího zájmu veřejnosti, médií a akademické sféry, než tomu je u maturitní zkoušky, k relativně radikálním změnám. Kurikulární reforma legislativně spuštěná školským zákonem (zákon č. 561/2004 Sb., o předškolním, základním, středním, vyšším odborném a jiném vzdělávání) si tak ve středním odborném vzdělávání vynucuje změny v oblasti evaluace výsledků vzdělávání, čímž se mění pojetí závěrečných zkoušek v učebních oborech (dále jen závěrečných zkoušek). Následující text podává situační zprávu o změnách v závěrečných zkouškách (ZZ) od roku 2003, dále sleduje způsob monitorování a závěrem poodhaluje záměry se ZZ v budoucnosti.

Následkem aplikace školského zákona došlo k zajištění účasti zástupců zaměstnavatelské sféry při závěrečných zkouškách. V důsledku nespokojenosti se stavem, kdy závěrečné zkoušky měly na různých školách ve stejném učebním oboru odlišnou úroveň náročnosti a odlišné pojetí, byla provedena analýza a navržen nový model závěrečných zkoušek. Postupně se vyvijjela koncepce nového modelu závěrečné zkoušky, jejiž finální verze byla zveřejněna v publikaci Koncepce nové závěrečné zkoušky v oborech středního vzdělání s výučním listem (Jezberová a kol. 2008). Pomocí podpůrných projektů je postupně realizován jednoduchý záměr, kdy závěrečné zkoušky jsou založeny na jednotném zadání (JZZZ) pro daný učební obor, které obsahuje témata pro všechny tři zkoušky (písemnou, praktickou, ústní). Jednotná zadání vytvárí řešitelské týmy složené z pracovníků odborných škol, pracovníka Národního ústavu odborného vzdělávání (dále jen NÚOV) a sociálního partnera - zástupce zaměstnavatelské sféry.

Na podporu těchto změn z rozhodnutí MŠMT byly postupně realizovány NÚOV jako přímo řízenou organizací MŠMT tři projekty. Ve školním roce 2003/2004 se jednalo o projekt „Pilotní ověřování jednotného zadání závěrečných zkoušek ve vybraných učebních oborech", v letech 2005 - 2008 o systémový projekt ESF Kvalita I (Vytvoření externího systému monitorování a hodnocení včetně zřízení Centra pro zjištování výsledků vzdělávání) a od roku 2009 s výhledem do jara 2012 je realizován individuální projekt národní „Nová závěrečná zkouška“. 


\section{KONCEPCE ZÁVĚREČNÝCH ZKOUŠEK}

Návrh koncepce závěrečných zkoušek, který v důsledku ověřování v rámci řešení projektu Kvalita I doznal v období 2005 - 2008 řady změn, Ize charakterizovat následujícími prvky:

- Centrálním vytvořením jednotného zadání závěrečné zkoušky pro každý obor středního vzdělání s výučním listem s využitím kvalifikačního standardu úplné kvalifikace daného oboru vzdělání uvedeného v národní soustavě kvalifikací (www.kvalifikace.cz);

- účastí zástupců zaměstnavatelské sféry (sociálních partnerů) na tvorbě JZZZ;

- zařazením nových obsahových prvků do závěrečné zkoušky (obecný přehled ze světa práce, samostatná odborná práce);

- vzájemnou obsahovou provázaností a praktickým charakterem jednotlivých zkoušek závěrečné zkoušky;

- možností doplnění JZZZ o specifika odborné prípravy uvedené ve školním vzdělávacím programu konkrétní školy;

- doplněním závěrečné evaluace žáka (tj. výsledků žáka dosažených u závěrečné zkoušky) o záznam jeho průběžné evaluace (výkaz odborných kompetencí žáka získaných v průběhu vzdělávání).

\section{PODPU゚RNÉ PROJEKTY NOVÉHO POJETÍ ZÁVĚREČNÝCH ZKOUŠEK}

Díky podpůrným projektům mohla být postupně vytvářena JZZZ pro jednotlivé učební obory (viz Graf 1 )

Ve školním roce 2003/2004 byl na vybraných školách realizován projekt „Pilotní ověřování jednotného zadání závěrečných zkoušek ve vybraných učebních oborech". JZZZ bylo realizováno v následujících učebních oborech: 23-68-H/001 Automechanik, 26-51-H/003 Elektrikář - silnoproud, 65-52-H/001 Kuchař. Projektu se zúčastnilo 34 škol s 1191 žáky.

Ve školním roce 2004/2005 v rámci projektu Kvalita I proběhlo ověřování 8 JZZZ pro 8 učebních oborů. Zúčastnilo se jej 80 škol, na kterých skládalo závěrečnou zkoušku 2158 žáků. Na několika školách bylo ověřování více JZZZ, celkem se jednalo o 112 školoborů ${ }^{1}$. V tomto roce bylo JZZZ ještě tišsěno centrálně v NúOV a distribuováno poštou na školy.

Ve školním roce 2005/2006 proběhlo v rámci projektu Kvalita I pilotní ověřování 19 JZZZ ve 22 oborech vzdělání. Do pilotního ověřování se zapojilo 135 škol a závěrečnou zkoušku skládalo 6014 žáků. JZZZ bylo v tomto roce již dodáváno vypálené

1 Počet školoborů - počet JZZZ realizovaných na školách. V některých školách probíhala závěrečná zkouška podle JZZZ ve více učebních oborech. 
na $\mathrm{CD}$ a školy si tiskly pro daný učební obor zadání samy.

Ve školním roce 2006/2007 bylo ověřováno 41 jednotných zadání závěrečných zkoušek v 50 učebních oborech. $V$ tomto roce byly poprvé využity při tvorbě JZZZ hodnotící standardy příslušné kvalifikace vytvářené v systémovém ESF projektu „Rozvoj a implementace národní soustavy kvalifikací", čímž se ještě více promítly do podoby závěrečných zkoušek požadavky světa práce. Do pilotního ověřování se zapojilo 200 škol a závěrečnou zkoušku skládalo 8163 žáků.

Graf 1:Vývoj jednotných zadání závěrečné zkoušky v učebních oborech

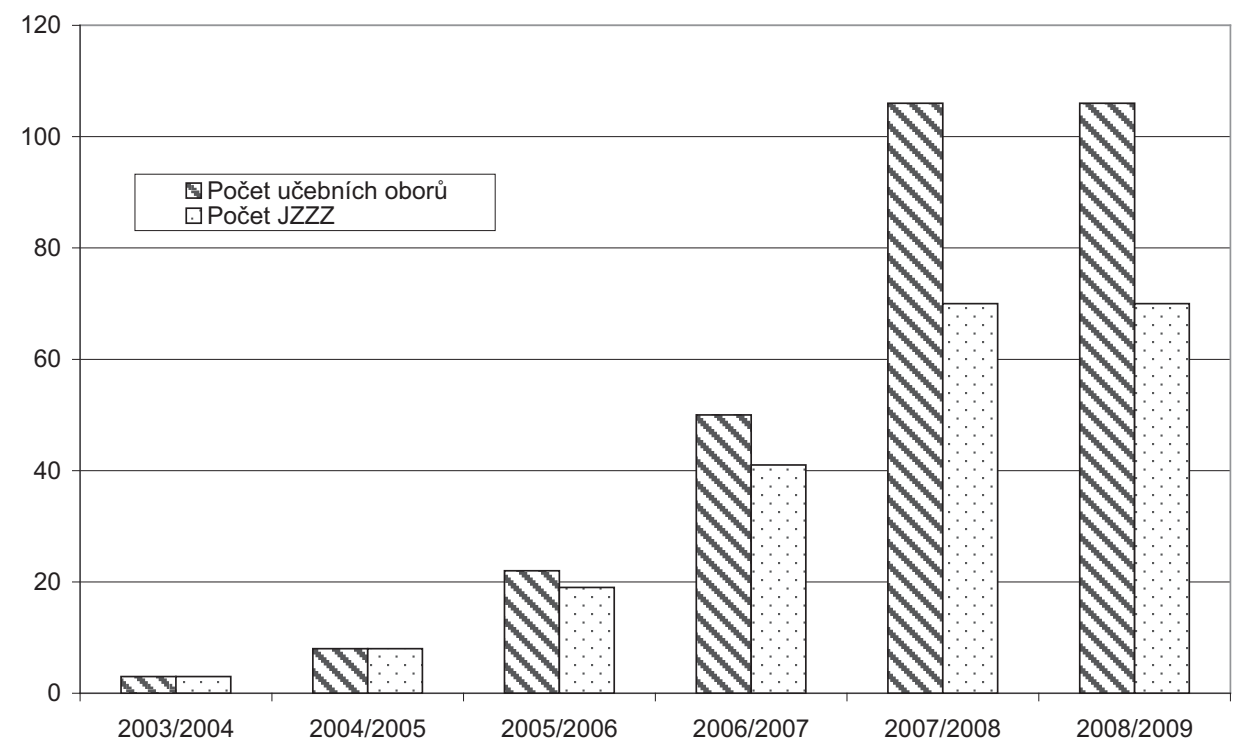

Ve školním roce $2007 / 2008$ bylo vytvořeno 70 jednotných zadání závěrečné zkoušky v 106 učebních oborech. Do projektu v rámci ověřování JZZZ bylo zapojeno 247 škol s 18000 žáky. Z důvodu ukončení projektu v červnu 2008 nebyly školám zadávány zpětnovazební dotazníky.

Ve školním roce 2008/2009 byla jednotná zadání závěrečných zkoušek poprvé zadána a distribuována prostřednictvím informačního systému vytvořeného v rámci projektu Kvalita I (webový portálu IS NZZ). Do informačního systému byla převedena všechna JZZZ vytvořená ve školním roce 2007/2008. Do ověřování bylo zapojeno 232 škol. 


\section{MONITOROVÁNÍ STAVU ZÁVĚREČNÝCH ZKOUŠEK NA ŠKOLÁCH}

Kvalita JZZZ je garantována několika vzájemně provázanými činnostmi:

- Zásadním prvkem je, že konkrétní řešitelské týmy, které vytvárí JAZZ, jsou složené z pracovníků odborných škol, které vyučují přílušný učební obor. Takže tito pracovníci mají praktické zkušenosti s tvorbou a realizací závěrečných zkoušek na své vlastní škole.

- Realizované závěrečné zkoušky jsou monitorovány odbornými pracovníky NÚOV, kteří jsou zároveň členy příslušného řešitelského týmu, tvořícího konkrétní JZZZ.

- Názory na JZZZ jsou získávány od škol prostřednictvím dotazníkového šetření. To je uskutečněno vždy v červnu - polovině července př́slušného roku, tj. v době, kdy končí závěrečné zkoušky na školách, a př́íslušní učitelé tak mají možnost vyjádřit se k pojetí a obsahu JZZZ.

\section{Řešitelské týmy}

V pětičlenných řešitelských týmech připravujících JZZZ pro učební obory byly a jsou určeny role jednotlivých členů. Na tvorbě JZZZ se většinou podíleli zástupci tři škol, z nichž jeden byl v roli gestora (koordinátor týmu), odborný pracovník NúOV a sociální partner - odborník z praxe. Při realizaci podpůrných projektů se ukázalo toto složení řešitelských týmů jako vyhovující a přispívající k všeobecnému přijetí JZZZ. Při tvorbě JZZZ pak týmy kromě vlastních zkušeností pracovaly na základě metodiky tvorby jednotného zadání s informacemi získanými z monitorovacích návštěv a z podnětů ze zpětnovazebních dotazníků k JZZZ.

Ve školním roce 2009/2010 jsou v souvislosti s tvorbou JZZZ v informačním systému řešitelské týmy (nyní „autorské týmy") složené z jednoho editora (interní pracovník NúOV nebo externí - zástupce školy), autorů (pracovníci ze dvou až tří škol) a odborníka z praxe.

\section{Monitorovací návštěvy}

Každý školní rok jsou v době konání závěrečných zkoušek, tj. na konci května a v červnu, uskutečňovány monitorovací návštěvy, které poskytují řešitelským týmům a vedení podpůrných projektů informace o průběhu závěrečných zkoušek. Jedná se o návštěvu školy, na níž se koná praktická zkouška či ústní zkouška v konkrétním učebním oboru odborným pracovníkem NúOV. Při návštěvě si pracovník zaznamenává na základě pozorování a na základě řízeného rozhovoru informace do formuláře pro monitorovací návštěvy. Monitoringy závěrečných zkoušek byly většinou zaměřeny na průběh závěrečných zkoušek, tj. na organizační zajištění ze strany školy, časový průběh zkoušky, způsob hodnocení žáků, úroveň připravenosti žáků, komunikace učitelů a žáků, činnost odborníka z praxe, názory zkoušejících na JZZZ. Za jednotlivé obory jsou potom formuláre vyhodnoceny a je vypracována komplexní zpráva o monitoringu průběhu závěrečných zkoušek. Poznatky z monitoringu jsou 
využívány pro účely upřesnění metodického postupu tvorby jednotného zadání ZZ pro konkrétní školní rok a dále při úpravách stávajících a tvorbě nových JZZZ pro další školní rok.

Ve školním roce 2008/2009 se při monitorování jednalo o zjištění prímých zkušeností s webovým portálem IS NZZ k jednotnému zadání (tj. vstup do informačního systému, hodnocení jeho uživatelského prostředí), hodnocení koncepce JZZZ a zjišsění připomínek k obsahu stávajícího zadání jednotlivých zkoušek apod., které byly zaznamenány do připraveného formuláře informačního systému.

Graf 2: Vývoj počtu zapojených škol a návratnosti dotazníků k JZZZ

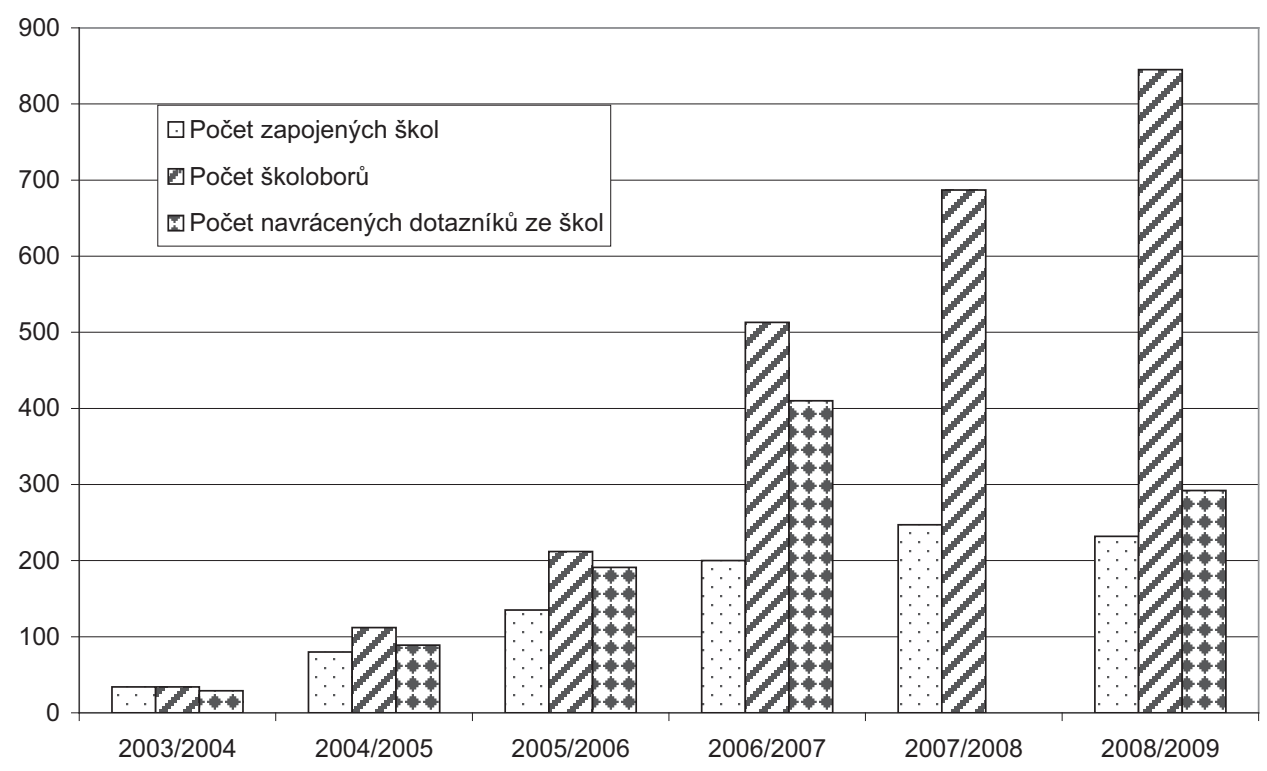

\section{Dotazníkové šetření}

V souvislosti s pilotním ověřováním jednotného zadání závěrečných zkoušek byl v podpůrných projektech vždy zúčastněným školám předložen dotazník, ve kterém byly zjištovány jejich názory na přípravu a realizaci závěrečných zkoušek podle JZZZ v učebních oborech. Zároveň byl předložen i dotazník odborníkům z praxe, kteří se závěrečných zkoušek realizovaných podle JZZZ účastnili jako členové zkušebních komisí. Dotazník pro školy byl většinou strukturován do základních okruhů (I. Příprava závěrečné zkoušky podle jednotného zadání; II. Realizace závěrečné zkoušky podle jednotného zadání; III. Názory školy na závěrečnou zkoušku podle jednotného zadání, IV. Názory na koncepci závěrečných zkoušek). Návratnost dotazníků byla zajištěna symbolickou odměnou pro respondenty ( $v$ letech 2003/2004 - 2006/2007 se pohybovala míra návratnosti dotazníku od 79,5\% - 90,1\%, v školním roce 2008/2009 byla míra návratnosti dotazníku 34,6 \%). Vývoj návratnosti závěrečných zkoušek je uveden v grafu 2. Návratností se rozumí poměr školoborů a navrácených dotazníků ze škol. Ve školním roce 2007/2008, kdy v červnu skončila podpora zajištovaná projektem Kvalita I, nebylo dotazníkové šetření realizováno. Ve školním roce 2008/2009 
je vysoký počet školoborů, tj. školami využitých JZZZ dán spuštěním informačního systému IS NZZ, který umožňuje plošné využití JZZZ (oproti předchozím rokům si některé školy stáhly jednotné zadání ve více oborech vzdělání).

Ve školním roce 2008/2009 byly prostřednictvím elektronického dotazníku v informačním systému získávány informace od škol o průběhu práce školy s IS NZZ, o posouzení celkové úrovně zpracování jednotného zadání, o identifikaci problémů ve zpracování jednotlivých podkladů jednotného zadání a vlastní vyjádření školy k práci s jednotným zadáním v IS NZZ.

\section{BUDOUCNOST ZÁVĚREČNÝCH ZKOUŠEK}

Podpưrné projekty postupně měnily $v$ učebních oborech pojetí závěrečných zkoušek. Jaké změny přinese současný projekt Nová závěrečná zkouška, který bude trvat do jara 2012?

Cílem projektu je zabezpečovat plošnou realizaci nové závěrečné zkoušky ve všech školách. Zajištění plošnosti především spočivá ve vývoji a implementaci webového portálu informačního systému nové závěrečné zkoušky (IS NZZ), který bude sloužit nejen k vlastní tvorbě JZZZ, ale už umožňuje i následné zprostředkování JZZZ školám. Systém již v současnosti shromažduje všechna vytvořená jednotná zadání i metodické materiály a zajištuje přístup škol k nim, v budoucnu pak napomůže i výměně zkušeností mezi pedagogy a dalšími odborníky.

Stanislav Michek 